1976

\title{
Rights of the Mentally Handicapped
}

Michael L. Perlin

New YorkLaw School, michael.perlin@nyls.edu

Follow this and additional works at: https://digitalcommons.nyls.edu/fac_articles_chapters

\section{Recommended Citation}

Perlin, Michael L., "Rights of the Mentally Handicapped" (1976). Articles \& Chapters. 1212.

https://digitalcommons.nyls.edu/fac_articles_chapters/1212 


\title{
Rights of the Mentally Handicapped
}

\author{
M ICHAELL R PERLIN, ESQ
}

Perhaps the most significant point that can be mate in discussing the "Rights of the Mentally Handicapped" is to analogize the development of the area to the "census clock" in the United States Census Bureat which reflects the nation's population at any given time: during the time it takes you to read the entire clock, the figures change substantially. So it is with the rights of the mentally handicapped.

Few, if any, other areats of the law have seen such majon changes and advances in the past five years as that of the substintive rights of those institutionalized in psychiatric hospitals. Virtually every significant decision is less than three years old, and, at with the census clock, the changes contimuc unabated.

In this volatile area, then, what can be referred to as "fluxiness" is the only absolute, a fact which, of course, probably makes precise definitions impossible. Perhaps, as a result, the whole area is being given far more scrutiny than ever before-a scrutiny which should be welcomed by all practitioners in the area. In that regard. for the first time, mental health rights, in becoming. substantively, a growth ficld, has become, to a modest extent, a growth area for the bar. As Statc Supreme Courts and Federal Courts come to acknowledge the role of counsel in mental health proceedings, ${ }^{1}$ a necessary corollary will be that there will continue to be more "mental health attorneys" practicing before the courts in the future than in the past several years (or perhaps decades) combined. Thus, any discussion of the "rights of the mentally handicapped" must. rather than merely presenting a bulletin-board compendium of each case decided. discuss the most important and conceptually troublesome areas of inquiry in some depth. a discussion which will raise questions of critical importance which still cannot be answered with any sort of finality.

Any discussion of the rights of the mentally handicapped must begin with the recent decision of the ('nited States Suprene Court in $O^{\prime}$ (ionnor 1 . Donaldson, 2 in which that court held, for the first tine in a mental health setting. that involuntary custodial confinement without treatment of a mental patient not dangerous to himself or others violates that patient's constitutional right to liberty. That case, which involved a patient who had spent 15 years in a Florida institution without a shred of evidence that he had ever posed a danger to himself or 10 others, was originally presented to the Supreme Court as a right-to-treatment action. a matter to be discussed in some depth below. The Court, however, declined to rule on that issue. limiting its finding to the delendant, "constitutional right to liberty."'3 noting:

A fiuding of "mental illness" alonc camot justily a State's locking a person up against his will and kecping him indelinitcly in simple custodial confinement . . there is no constitutional basis for confining "mentally ifl" peroms insolumtarily if they are dangerous to no one and can live silfely in freedom.

... May the state fence in the hatmless mentally ill solely 10 save its citizens from exposure to these whose wats are difterent: One might as well ask if the State, to asoid public uncase. could incarcerate all who are physically unattractive or socially eccen-

\footnotetext{
- Mr. Perlin is Ditector of the Department of the Publir Advecate, Division of Mental Health Advocacy, State of New Jemes.

Portions of the article have previously appeared in the New Jersey Law fournal. Dec. 18, 1975, 98 N.J.1.J. 1057.
} 
tric. Mere public intolerance or animosity cannot constitutionally justify the deprivation of a person's phy'ic al liberty...

... A State cannot constitutionally confine without more a nondangerous individual who is capable of surviving sately in freedom by himsell or with the help of willing and responsible fanily members or friends. Since the jury found, upon ample evidence. that O'Connor, as an agent of the State, knowingly did so confine lonaldson, it properly concluded that o'(onnor violated Donaldson's constitutional right to freedom. ${ }^{4}$

However, for all of the ballyhos. Donaldson may turn out to be nothing more than a paper tiger in many staten. Certainly, in many jurisdictions, a dangerousness standard has been-and continues to be-the appropriate test for commitment both at final hearings. and for temporary confinement. ${ }^{6}$ 'The impact of lomaldson, therefore, will most likely be symbolic rather than actual-although it cover no new ground as far as the law in many jurisdictions is concerncel at initial commitments, it should serve as a wanning that, even after commitment, such dangerousness must continue to justify continuation of confinement, ${ }^{7}$ and that, therefore, there must be equally great scrutiny of the recond for daugerousness at a habeas corpus or periodic review hearing. Also, Donaldson is the first case in which the linited States Supreme Court has addressed itself squarely to constitutional issues involving ciolly committed patients-in doing so, the Court took its first step on the unchartered road which it moted in Jackson \%. Indiana, ${ }^{\times}$where it commented, "It is perhaps remarkable that the substantive constitutional limitations on [involuntary commitment] power have not been more frequently litigated."'s Donaldson is, probably, a harbinger of future decisions in this area.

The major thrust of recent developments in mental health law, though, has been in the area of right to treatment. It is on this batteground that the major theoretical and practical wars have been and are being fought, and it is in the attempted furtherance of this right that the dramatic class actions have been brought.

Historically, the right was first mentioned in a 1960 American Bar Association Journal article by Morton Birnbaum. Simply stated, Birnbaum-who is a doctor as well as a lawyer-argued that legally (as well as morally and ethically). if the State confines an individual under the benevolence of the parens patriae doctrine, it must treat him as wcll." Mthough this hardly sounds like the most radical of ideas. interest in the theory didn't exactly scamroll. In fact, it was not cited in a case until 1966, when, in a habeas copus action brought by an inmate (committed following an insanity acquittal) alleging he received no treatment in Washington's St. Elizabeth's Hospital, the District of Columbia Circuit reversed the District Judge's denial of the petition. finding a statutory right to treatment, and remanding for a factual hearing." Hethough the case was decided on a statutory hasis. Chief Judge Bazelon-one of the true giants in this field--noted that a total absence of treatment might call into play the duc process, equal protection, and cruel and unusual punishment clatuses of the Constitution.

That case. Rouse: t'. Cimmerm, was thus the ice-breaker-of a sort. As Harvard Professor of Law and Povhiatry Nan Sune has noted. ". After Rouse, the right to treatment became something to be talked about, but what was it:"12. Although mention of the right resurfaced briefly in a Massachuncter case brought by an inmate comnitted following a determination that he would never be competent to stand trial on a criminal charge, in which the court ruled that wh commiment without treatment would create a "substantial risk" of violating the equal protection and due proces clauses, ${ }^{13}$ realistically, it lay dormant until the landmath case of $\|$ vatt $i$. Stickney, ${ }^{14}$ which repainted the landscape for all time.

Without indulging in cxcesive hyperbole, it an be said that Wyat burst onto the mental health law wene in the ame manner as the first performance of Stravinsky's "Rites of Spring" exploded in the Parisian musical world or the first showing of Duchamps" "Vude Dencending a Staircase" rocked New York art salons-its impact cannot 
be exaggerated. Wyatt, whose origins were rooted in an obscure and internecine labor dispute among Nabamat hospital workers, attained its significance for a variety of reasons: it was a class action on behalf of civil paticuts (the first of its kind). filed by the prestigious Mental Health Law Project of Washington, D.C.., against all Alabama institutions, accompanied by much national publicity; the action was brought in the state which ranked, at the tine of filing. 50 th out of 50 in terms of mental health per capita spending; supporting the action were many prominem amici, including the American Psychological Association, the American Orthopsychatric Association, the American Association on Mental Deficiency, and the A.C.L.I'. (to be joined later by the National Association for Mental Health and the National Asonciation for Retarded Children); and the case was brought before the preminemt activist federal judge in the south--Frank Johnson.

Judge Johnson, of couse, ruled that the mentally ill hase a "constitutional right to receive such treatment as will give them a reasonable opportunity to be cured or to improve his or her mental conditions," 1.5 and that. to fulbll this treatencent right. there must be a humane physical and psycloolegrical environment, qualified staff personnel in sufficient numbers, and individualiacd treament plins for each patient ti the application of the due process clause is squatrely premised on the Inited States Supreme Court's holding in Jachson $r$. Indiana, ${ }^{17}$ that "due process tequires that the nature and duration of commitment bear some reasonable relation to the purpose for which the individual is committed."18

In affrming the District Cout's decisions, 19 the: Fifth Circuit relied heavily"n on its decision several months earlier in lonaldion o. O'Connor:21 Although the Inited states Supreme Court's vacation of the decision in that case declined to rule on the question of a constitutional right to treatment. the constitutional basis of the Fifth Cincuit's decision may still be seen as valid.:?

The constitutional right has been similarly found in at least two other cases of national significance. 23 and wits extended $x$ as to reject the argument of "good faith" as a defense. 24

In addition to the duc process basis, the constitutional right to treatment is also seen as resting on the cruel atud unustal punishment clause. found specifically applicable w mental hospitats in Rozeckir. Cinughan and dereloped in the comext of jail and prison conditions suits," $=$ and on the equal protection clause, on the theory that. because involuntary civil comnitment insolves fundamental rights, egual protection requires that the classification meet the "compelling state interest" test;:- thus, on justly confunement and provide the rationale for commiment, the state must provide suitable treatnent. ${ }^{-x}$

These developments in the right wo treatment, of course. further pomise an expansion of the right, greater surveillance of right entorcement and. evidently, extended judicial involvement in the area. .1ll of which raises at least fore relesant questions which hase been and are being raised in analogous contexts clocwhere.

First, is this a proper anca for judicial creativity: Clearly, the answer to that must be "yes" if the inuce is couched in term of vindication of fundamental constiutional rights.29

Secondly, can decisions be reudered without tuming the judicial wstem into an institutional overece? The anewer here is "Yes probably" Come ane understandably loath

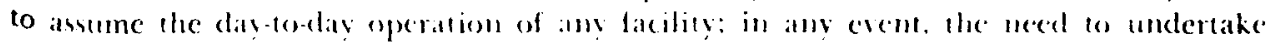

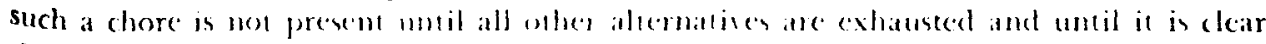
that defendans refure 10 comple with coun onders bince there in abolutely no reason

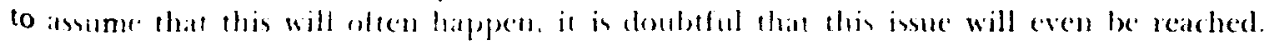

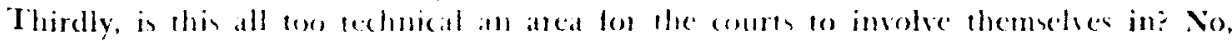

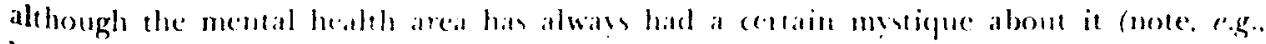

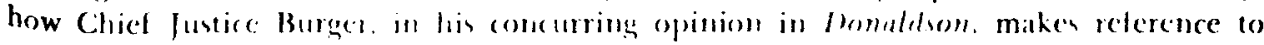

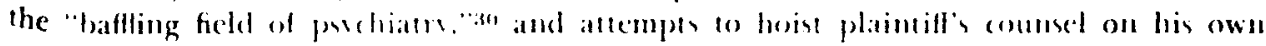


petard by citing one of counsel's articles in support of the proposition that "many forms of mental illness... are not understood ... [and that there is] . . uncertainty of diagnosis and ... tentativeness of professional judgment [in this field]" $),{ }^{31}$ adjudicating cases here is no more technical than in other areas where expert testimony is heavily relied on. In fact, conversely, it is clear from $\mathrm{W}^{\prime} y a$ t $^{32}$ and Lavis $\%$. W'atkins ${ }^{33}$ that experts here will be far more likely to agree on treatment standards than in most other areas involving expert opinion evidence. Finally, the majority in Donaldson specifically rejects defendant's claim that adequacy of treatment is a "nonjusticiable" question as "unpersuasive," premising its decision on Jackson $v$. Indiana. ${ }^{34}$

Fourthly, will court actions in this area lead to what has been termed by some "the therapeutic state"? Not according to Professor Nicholas Kittrie, the creator of that term:

To some, the formulation of this concept, which curtails the state's therapeutic power through legal supervision. may sound like a call for undue judicial and legal interference with medical and therapeutic prerogatives. To others, this development is a mere annunciation that this nation's fundamental tool for the promotion of national aims and the protection of individual rights-the system of checks and balances-is finally reaching into the dark corners of the institutions entrusted with the thankless role of storing, curing, and rehabilitating those who deviate from society's norms. ${ }^{35}$

\section{Faced with a similar question. the District of Columbia Circuit Court noted: ${ }^{36}$}

We do not suggest that the court should or can decide what particular treatment this patient requires. The court's function here resembles ours when we review agency action. We do not decide whether the agency has made the best decision, but only make sure that it has made a permissible and reasonable decision in view of the relevant information and within a broad range of discretion.

Finally, will decisions in this area merely reenforce the model of large state psychiatric institutions as the paradigmatic modality of treatment? Although the answer to this question, obviously, does not turn on any determination as to the propriety of judicial involvement, it is relevant to the dynamics of mental health litigation. The most definitive answer here is "maybe"-however, nationwide, institutional conditions are a fact of life. Although there are clearly movements about to introduce deinstitutionalization programs and spur the development of alternative care facilities, such programs move slowly. While they are in various stages of development, the rights of institutionalized patients should (and must) be vindicated through the legal system. To do otherwise would be to concede the loss of an entire generation of patients, a sacrifice which cannot be embraced.

Beyond the question of the right to treatment, however, there are other significant recent developments in the law of mental health rights which must be considered in order to understand fully the extent of movement in this area in recent years. Thus, the Hillowbrook case 37 premised its holding on the existence of a right to freedom from harm. a basis for decision usually associated with jail or prison suits. $3 x$ There, it was reasoned that. just as persons who live in state custodial institutions are owed certain constitutional duties by the state and its officials, 39 the duty owed is even higher in a non-penal or non-incarceratory setting. "t"

Among the rights owed to patients within the general rubric of a "right to freedom from harm" (based on a compositc Eighth Amendment/Fourtecuth Amendment argument) are "a tolerable living cnvironment."1 protection from physical harm," correction of conditions which violate "basic standards of human decency,"t3 opportunity to exercise and have recreation, ${ }^{4+}$ and the "necessary elements of basic hygiene." 4 " In addition, mental patients are owed a duty by those charged with their custody "to preserve... their life, health and safety: beyond any duty owed to the general public,"16 as well as a therapeutic, not punitive, confinement ${ }^{\text {i }}$ In another area of relevant comparison, it 
is clear that there is a greater duty owed to a patient in a hospital specializing in the treatment of mental disorders than in a general hospital. ${ }^{48}$

A further argument can be made that patients have a constitutionally protected right to be secure in the privacy of their own bodies against invasion by the state except where necessary to support a compelling state interest. ${ }^{49}$ Just as this right has been held to apply to cases in which prison medical personnel treat prison inmates, ${ }^{50}$ so must it be held to apply to patients in a state psychiatric hospital.51 Finally, it has been held that the administration of apomorphine-a drug which induces massive vomiting and which was used as "aversive stimuli" in treating non-consenting mental hospital inmates who allegedly presented behavioral difficulties-constituted "cruel and unusual" punishment, even though it was characterized as "treatment." 52

A body of law has similarly developed regarding the mentally handicapped's right to the "least restrictive alternative" setting for treatment. That doctrine holds that, although a government's purpose may be both "legitimate and substantial, that purpose cannot be pursued by means that broadly stifle personal liberties when the end can be more narrowly achieved," 53 and, in a mental health setting. stands for the proposition that courts "must refrain from ordering hospitalization whenever a less restrictive alternative will serve as well or better the State's purpose," 54 or that the Constitution requires an affirmative demonstration that no suitable less restrictive alternative exists prior to involuntary hospitalization.5.5 The doctrine similarly applies to situations in which a patient is in a more restrictive setting than is therapeutically necessary. ${ }^{56}$

The constitutional bases for the right are many: $A$ person committed to a psychiatric hospital suffers curtailment of his constitutionally protected rights to travels7 and to associate freely with others, ix as well as constriction of his otherwise-protected rights to peacefully assemble, communicate, practice religion and enjoy sexual privacy.58 And, of course, such commitment constricts the individual's right to physical liberty and freedom. 60

Finally, the overwhelming weight of medical authority supports the use of less restrictive environments both within and without psychiatric institutions for therapeutic, emotional. financial and practical reasons. ${ }^{61}$ The applicability of this right can thus no longer be seen as in doubt.

In addition to these areas of substantive law, there have been significant recent developments in the area of the right of the handicapped to exercise their civil rights while institutionalized. This category includes, but is not limited to, cases in which courts have held that the mentally handicapped have the right to exercise a First Amendment freedom of thought, ${ }^{62}$ to refuse uon-emergency medical treatment on religious grounds, ${ }^{63}$ to not be excluded from :he educational process, ${ }^{34}$ to be protected by a durational limitation on the term of commitment, 6.5 to be compensated for economically-beneficial work done, ${ }^{66}$ and to not be barred from registering (1) vote merely because of their status as residents at a State school for the retarded.67

In addition, in the prison and/or jail context, First Amendment rights to gather for religious services, prepare diaries, communicate by mail. make telephone calls, read nonseditious literature. reccive vivitors and maintain access to comnsel have been upheld. ${ }^{88}$ As the right to freedom from harm for the mentally handicapped has developed from case law originally stemming from jail and prison conditions settings, ${ }^{69}$ so it can be expected that the First Amendment cases will similarly develop.

Again, this list is not exhaustive-it reflects only a sampling of reported litigation in this area.

In summary, then. the developments of the law of mental patients' rights has been and remains explosive. As time goes on, more suits will be filed and the body of case law will continue to grow, thus fulfilling Mr. Justice Blackmun's litigation prophecy in Jackson $"$ Indiana." What has been seen so far is, indeed, only the tip of the iceberg. 


\section{References}

1. The right to counsel at involuntary civil commitment proceclings has becn found in, inter alia, Heryford v. Parker, 396 F. 2d 393, 396 (10 Cir. 1968); Lesward 7. Schmidt, 349 F. Supp. 1078 (E.D. Wis. 1972), vacated on other procedural grounds 414 I.S. 473 (1974), on remand 379 F. Supp. 1376 (E.D. Wis. 1974), vacated and remanded-I.S. -, 43 L.S.L.W. 3600 (1975); In re Barnard, 455 F. 2 (1 1370 (D.C. Cir. 1971); Dixon it. Allorvey General of Pennsylvania, 325 F. Supp. 966 (M:D. Pa. 1971); Lynch y. Bax/ey, 386 F. Supp. 1085 (M.I). Ala. 1974); Bell v. Wayne Cointy (ieneral Hospital, 387 F. Supp. 1085 (E.I). Mich. 1974); Denton v. Commonweallh, 383 S.W. 2 d 681 (Ky. App. 1961); Slale ex rel Hawks 7. Lazaro, 202 S.E. 2d 109 (W. Va. Sup. C. App. 1974); In re Fivher, 39 Obio St. 2d 71, 313 X.E. 2d 851 (Sup. (.t. 1971); In re Hajes, 18 N.C. App. 560, 197 S.E. 2 d 582 (Ct. App. 1973); In re Collman, 9 Ore. App. 496, 497 P. $2 d 1233$ (Ci. App. 1972); In re Adams, 497 P. 2d 1080 (Okla. Sup. Ct. 1972); Stale ex rel Richey v. Superior Court, 59 Wash. 2d 872, 371 P. 21 51 (Sup. C. 1962).

It is clear that counsel plays a critical and, in some cases, nearly dispositive role in involuntary commitment proceedings-where active attorneys ane employed, fewer persons are committed. See Developments in the law-Civil commitnent of the mentally ill. 87 Harv. L. Rev. 1190, 1285 (1974)

Two clear conclusions may be drawn from statistical surveys: a large percentage of state hospital patients call be safely treated elsewhers: the number varying from $43 \%$ to $68 \%$ to $7.5 \%)$, and, where counsel is operative, the number of commitied persons plummets, especially when compared with persons not represented by coumsel. Sce, e.g., Scheff: Being Mentally Ill $168(7 \mathrm{th}$ ed. 1973) (the presence of $43 \%$, of patients in hospitals studied could not be explained in terms of their piychiatric condition); Abraham and Bucker: Preliminary findings from the psychiatric inventory 3 (1971) (68\%" of patient population at St. Elizabeth's Hospital in Washington not considered dangenous to themselves or others), and Mendel: Brief hospitalization techniques. 6 Current Psychiatric Therapies 310 (1966) (75\% of patients with diagnosis of schizophrenia studied could be suitably discharged), as cited in Ferleger: A patient: rights organization: Advocacy and collective action hy and for inmates of mental institutions. 8 Clearinghouse Rev 587 , $\mathrm{n} 1$ (1975).

Perhaps even more significant are studies showing that psychiatrists are no more significantly predicticly accurate than non-psychiatrists (e.g., lawyers). Sec Rappeport, Iassen and Gruenwald: Evahuation and follow-up of hospital palients who had sanity hearings, in Rappeport ed., Clinical Evaluation of the Dangerousness of the Mentally Ill 89 (1969) ("The comparison betreen court released and hospital released adjustment rates shows no signifi. cant difference in the predictive accuracy of either institution"), and Ennis and Litwack: Psychiatry and the presumption of expertise: Flipping coins in the courtroom, 62 Calif. L. Rev. 693, 749 (1974) (no evidence found that a psychiatrist can predict daugerousness more than a lawyer). In fact, a recent report prepared by the American Psychiatric Association concludes that "no reliable means exists for predicting whether an individual is likely to perform a violent act." APA. Clinical Aspects of the Violent Individual 23-30 (1975), discussed in News and Notes, 26 Hosp and Commun Psych 249) (April 1975).

And, of course, in the famous study of the so-called "Baxstrom patients" (those persons ordered released from lew Yok's maximum security facilities for "insane criminals" following the decision in Baxstrom $v$. Herold, 383 L.S. 107 (1966)), it was found that, of the 969 Baxtsrom patients who had presiously been statutorily incarcerated in maximum security facilities, within one year, only setien were recommitted to such a facility on a finding of dangerousness although it had been predicted by hospital officials that nearly 250 would need that type of security), and, of the 147 patients released to the community, only one had been amested within that time period (for petty larceny). Hunt and Wilcy: Operation Baxstrom after one year. $124 \mathrm{Am} \mathrm{J}$ Psych 124 (1968), reprinted in Association of the Bar of the City of New York: Mental Illness, Due Process and llic Criminal Defendant 224 (1968). For a more recent craluation and survey of the relevant litcrature sce Steadman and Cocnzra: lle cant predict who is dangerous. Psychology Tolay 32 (January 1975). See also Wenger and Fletcher: 1 he effect of legal counsel on aimissions to a statc mental hospital: A confromation of profersions. $10 \mathrm{~J}$ Healih and soc Behav 66. 69 (1969), in which $74 \%$ of represented persons were released, while only 90 , not represented were discharged.

Thus, whereas approximately $50^{\circ}$; of all persons picked up in Washington, D.C., had been committed in the past, the intertention of the Patient Advocacy Service of the Washington, D.C. Public Defender reduced that number to $\mathrm{I}^{\mathrm{c}} \mathrm{g}$. Silverberg: The civil commitment process: Basic comiderations, in I Legal Rights of the Mentally Handicapperl 103, 109 (P.L.I. ed. 1973). Sturlies of the Mental Health Information Service of New York reveal that $40.4 \%$ of all patients who had iequested hearings ihrough counsel were released by psychiatrists prior to the hearing-Kumasaka and Stokes: Involuntary hospitalization: Opinions and attudes of puchiatrints and lawyers. 13 Comprehensive Psych 201 (1972); 
Kramer: Protective legal services for the mentally ill. 23 Hosp. and Commun Psych 41, 42 (1972)-and that "intervention by coumsel actiug as paticnt's attorney tremendonsly increases chances of discharge, not to mention the other altenlutives to hospitalization that may also be worked out to the patient's sativfaction." (iupta: New Yoik's Mental Health Information Service: An experiment in due process." 25 Rutgers I. Rer. 405, 438 (1971) (emphasis added).

2. 422 U.S. 563, 4.9 C.S.L.W. $4929(1975)$.

3. Id. at 4932

4. Id. at 4933

5. See, e.g., N.J.S.A. 30:4-44; In re Heukelrkian, 24 X.J. Super. 407, 409, 94 A. 2 d 501 (App. Div. 1953).

6. See, e.g., ․J.S.A. 30:4-82; Stule 1. Caralluzzo, 49 ․J. I52, 156-157, 298 A. 2d 693 (1967); N.J. Ct. R. 4:74-7(f) (revised September 8. 1975); State v. Krol, 68 X.J. 236, - 4 . 2d-(1975), slip op. at 23.

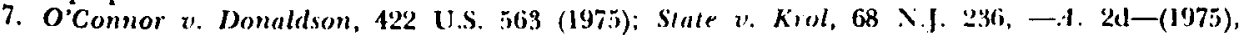
slip op. at 28, n. 12 ("lack of dangerousness is now also a ground for final release")

8. 406 U.S. $715(1972)$

9. Jackson $v$. Indiana, 106 U.S. 715,737 (1972)

10. Birnbaum: The right to treatment. 46 A.R.A.J. 499 (1960)

11. Rouse v. Cameron, 373 F. 2d 451 (D.C. Cir. 1966)

12. Stonc: The right to treatunent and the medical establishmemt. 2 Bull. Am. Acad. Psych. \& L. $159,161(1974)$

13. Nason v. Superintendent of Bridgeu'ater State Hospital, 339 Mass. 313, 233 N.E. 2d 908, 913 (Sup. Jud. Ct. 1968)

14. 325 F. Supp. 781 (M.I). Ala. 1971), 331 F. Supp. 1311 (.J.I). Ala. 1971), 314 F. Supp. 373 (M.D. Ala. 1972), 344 F. Supp. 387 (M.D. Na. 1972), aff'd sub. nom. IFiall v. Idevholt, 503 F. $2 d 1305$ (5 Cir. 1974)

15. Wyatt $v$. Stickney, 325 F. Supp. $781,78.4$ (M.1). Ala. 1971), affd sub. nom, Iy y"l \%. Aderholl, 503 F. 2 d 1.305 (5 Cir. 1974)

16. Wyatl v. Stickney. 334 F. Supp. 1341, 1343 (M.l. Nla. 1971), aft'd sub. "Wom. Wyall 7. Aderholt, 503 F. 2d 1305 (: Cir. 1974)

17. 406 U.S. 715 (1972)

18. Jackson $v$. Indiana, 406 U.S. 715,738 (1972). For a survey of recent literature on the "right to treatment," sec Schwitzgebel: Implencinting a right to eflective treatment. [1975] $L$. Psych. Rev. 117, 1. 1.

19. Wyalt v. Aderholt, 503 F. 2d 1305 (5 Cir. 1974)

20. Wyalt v. Aderholt, 503 F. 2d 1305, 1312-1315 (5 Cir. 1974)

21. 493 F. 2d 507 (5 Cir. 1974), vacaled and remanded on other grounds sub. nom. O'Connor v. Donaldson, 422 U.S. 363 (1975).

The Fifth Circuit there noted:

[P]ersons committed under what we have termed a porrw fration ground for commitment must be given ireatment lest the involumtary commitment amounds on an arbitrary exercise of govermment power proscribed by the due precen clatuse. . The second part of the theory of a due process right to treatment is based on the principle that when the three central limitations on the government's power to detaitu-that detemtion be in retribution for a specific offens; that it be limited to a fixed term; and that it be permited after a proceding where fundamental procedural safeguards ane olserved-are absent, there must be a quid pro quo extcoled by the goverument to justify confinement. And the quid pro quo most commonly recegnimed is the provision of rehabilitative treate ment, or, where rehabilitation is impossible, minimall aleptatte habilitation and care beyond the subsistence level cusertial care that would be posided in a penitemians $493 \mathrm{~F}$. 2d at $521-522$.

The court surveyed the procelural contexts in which attacks on the nature of non-penal confunement arose and found, matly unanimously, that there must be a quid pro quo for confunement in circumstances "where the conventional limitations of the criminal processes are inapplicable." $193 \mathrm{~F}$. 20d at 53 . I he cases included: (a) habeas ron pus pelitions brought by citizens helel under mon-penal confinements in conectional facilitien for convicts, e.g., Benton r. Reid, 231 F. 2d 780 (1).C. Cil. 1956); In re Mathlox, 351 Mich. 358, 88 X.W. 2d 470 (Sup. Ct. 1958): Miller v. Oreetholser. 206 F. 2d 415 (1).C. Cir. 1953); (b) holdings that persons under non-penal confinement must be held in places where conditions were actually therapeulic, e.g., Ragsdale r'. Oreholser, 281 F. 2d 948 (I).C. Cir. 1960): Darmell v. Cameron, 348 F. Ld 6t (D.C. Cir. 1965); (ommonueallh r. Page. 3.39 Mass. 313, 159 N.E. 2d 82 (1958); (c) decisions involving the confinement of habitual criminal offenders 10 provide rehabilitation, conditioning the constitutionality of such stames upou the realization of the satutory promise of rehabilitation, e.g.. Sas 2 . Marylınd, 334 F. 2d 506 15 Cir. 1964); cert. dismissed 
as improvidently granted $u b$. nom. Murel $r$. Baltimore City Criminal Court, 407 I'.S. 355 (1972); Davy r. Sullivan, 354 F. Supp. 1320 (M.I). Ala. 1979); (d) habeas enpus petitions challenging non-penal confinements on grounds of lack of treatment in combination with other grounds, e.g., Stachulak i. Coughlin, 364 F. Supp. 686 (X.I). Ill. 1973); Humphey r. Cady, 405 U.S. 504 (1972); (e) federal cases secking injunctive and declaratory relief requir. ing adequate treatment be provided in state-run facilities, e.g., Wyatt $\%$. Stickney, above: Nelson v. Heyne, 491 F. 2d 352 (7 Cir. 1974): Inmates of the Boys Training School $\%$ Affleck, 346 F. Supp. 1354 (D). R.I. 1972) (juvenile delinquents); Marlarella v. Kelley, 349 F. Supp. 575 (S.I). X.Y. 1972) ("persons in need of supervision").

22. In the course of its opinion, the Supreme Court vacated the Court of Appeals' judgment which affirmed a jury verdict of both compensatory and punitive damages on plaintiff's behalf in light of its intervening decision in Wood $v$. Strickland, - C.S.-., 43 I. Fd. 2d 214 (1975), which altered the scope of a state official's qualified immunity under 42 I.S.C.A. $\$ 1983$, premising the existence of such a violation on the official's knowledge that his action either "would violate [one's] constitutional rights... or [maliciously intended] to cause a deprivation of constitutional rights." 43 L.S.L.IW. at 4934. In remanding the case for reconsideration only of the monetary damages issue in light of Wood, above, the Court noted that "our decision vacating the judgment of the Court of Appeals deprives that court's opinion of precedential effect, leaving this Court's opinion and judgment as the sole law of the case," id. at n. 12, citing L'nited States $v$. Munsingwear, 360 L.S. 36, 40 (1950). A close reading of Munsingwear, however, reveals that the issue there was the res judicata effect of the judgment rather than the general precedential effect of such juigments on other actions; the comment herc, then. should be read to rob the Fifth Circuit's opinion of precedential effect only as it relates to further proceedings on remand with respect to damages in the Donaldson litigation itself. Cf. concurring opinion of Burger, C.J., 49 U.S.L.W. at 4935 .

23. Welsch v. Likins, 373 F. Supp. 487, 493 (D. Minn. 1974): Davis 1. Watkins, 384 F. Supp. 1196, 1203-1212 (N.D. Ohio 1974).

It should also be noied that, where a Federal Court in Georgia (relatively contemporancously with the District Court Wyatt decision) had held there was no such constitutional right to treatment, the Fifth Circuit reversed per curiam on the basis of its $W$ yall dccision and the Supreme Court denied certiorari. Burmham v. Deparment of Public Heallh of Cieorgia, 342 F. Supp. 1335 (N.D. Ga. 1972), rev'd per curiam 503 F. 2 d 1319 (5 Cir. 1974), cert. den.-U.S.-, 43U.S.L. IV. 3683 (1975)

24. The Welsch court thus held:

[G]ood faith is not at issue here. . . It does not suffice .. . to show that conditions have been upgraded at [defendant hospital]. that the situation will continue to improve in the future, and that even more achievements would be forthcoming were it not for the restrictions imposed by the legislature. It is the Court's duty uncler the Constitution, to assure that evcry resident of [defendant hospital] receive at least minimally adequate care and treatment consonant with the full and true meaning of the due process clause. 373 F. Supp. at 498 .

25. 459 F, 2d 6 (1 Cir. 1972)

26. See, e.g., Hamilton v. Loxe, 328 F. Supp. 1182 (E.D. Ark. 1971); Holl v. Sarter, 309 F. Supp. 362. 384 (F.D. Ark. 1970), aff'd 442 F. 2d 304 (8 Cir. 1971); Rhem v. Malcolm, 371 F. Supp. i94, 628 (S.D. N.Y. 1974), aff d 507 F. 2 d 339 (2 Cir. 1974).

27. Dunn ". Blumstein, 405 I'.S. 330,742 (1972).

28. See generally, Fricdman and Halpern: The right to treatment, in 1 Legal Rights of the Mentally Handicapped 273, 280-283 (P.L.I. ed. 1973); cf. Stale v. Krol, 68 N.J. 236, -A. 2d(1975), slip op. at 16 .

Where, in his original opinion on a motion for a preliminary jnjunction brought by residents of the notorious Willowbrook facility, a New York Federal Judge declined to find such a right to treatment ipremising his decision instead on the existence of a right to freedom from harm, New York Slate Association for Retarded Children, Inc. v. Rockefeller, 357 F. Supp. 752, 764 (E.D. X.Y. 1973) [hereinafter referred to as Willowbrook I]), in his later decision on a motion to accept a consent judgment, the same judge noted, referring to Wyatt, inter alia:

Somewhat different legal rubrics have been employed in these cases-"protection from harm" in this case and "right to treatment" and "need for care" in others. It appears there is no bright line separating these standards.

Neu. York State Assoriation for Retarded Childien r. Carey, 993 F. Supp. 715,719 (E.D.

N.Y. 1975) [hereinafter referred to as Willoubrook II]

29. See, generally, Enited States v. Carolene Products Co., 904 U.S. 144, 151, 11. 4 (1938), and see Siate $\%$ Krol, 68 … 236, -A. 2d- (1975), slip op. at 26 (calling for "a high degree of judicial flexibility and imagination"). 
30. O'Connor v. Donaldson, -U.S.-, 43 U.S.L.W. 4929, 4934, n. 2 (1975).

31. O'Connor v. Donaldson, -U.S.-, 4.9 U.S.L.W. 4929, 1936 (1975).

32. Wyatt v. Stickney, 344 F. Supp. 373 (M.I). Ala. 1972), 344 F. Supp. 387 (M.1). Ala. 1972), aff'd sub. nom. Wyatt v. Aderholt, 503 F. 2d 1305 (5 Cir. 1974)

33. 384 F. Supp. 1196 (N.D. Ohio 1974)

34. O'Connor v. Donaldson, -U.S.-, 43 U.S.L.W. 4929, 4933, n. 10 (1975).

35. Kittrie: The Right to Be Different, 398-399 (Pelican ed 1973)

36. Tribby v. Cameron, 379 F; 2d 104, I05 (D.C. Cir. 1967)

37. Willowbrook I, 357 F. Supp. 752, 764 (E.D. N.Y. 1973); Willowbrook II, 893 F. Supp. 715 , 719 (E.D. N.Y. 1975)

38. See e.g., Hamillon y. Love, 328 F. Supp. 1182 (E.I). Ark. 1971); Holl \%. Sarver, 309 F. Supp. 362, 384 (E.D. Ark. 1970), aff'd 442 F. 2d 204 (8 Cir. 1971); Rhem $v$. Malcolm, 371 F. Supp. 594, 628 (S.D. N.Y. 1974), aff'd 507 F. 2 d 333 (2 Cir. 1974); Detainees of Brooklyn House of Detention v. Malcolm, 520 F. $2 \mathrm{~d} 392$ (2 Cir. 1975).

39. Willowbrook I, 357 F. Supp. 752, 764 (E.D. N.Y. 1973)

40. Lollis v. New York State Department of Social Services, 322 F. Supp. 473 (S.D. N.Y. 1970), modified 328 F. Supp. 1115, 1118 (S.D. X.Y. 1971). Sec also, Rozecki \%. Gaughan, 459 F. 2d 6 (1 Cir. 1974); Martarella v. Kelley, 349 F. Supp. 575, 585 (S.I). N.Y. 1972); Inmates of Boys Training Schools $v$. Affleck, 346 F. Supp. 1354 (D. R.I. 1972); Burt: Eighth amendment rights in mental institutions, in 2 Legal Rights of the Mentally Handicapped 735, 737 (P.L.I. ed. 1973)

41. Willowbrook 1, 357 F. Supp. 752, 764 (E.D. N.Y. 1973); Welsch \%. L.ikins, 373 F. Supp. 487, 502-503 (D. Minn. 1974)

42. Hamilton v. Love, 328 F. Supp. 1182 (E.D. Ark. 1971); Rhen v. Malcolm, 371 F. Supp. 594 , 628 (S.D. N.Y. 1974), aff'd 507 F. $2 d 393$ (2 Cir. 1974)

43. Brenneman v. Madigan, 343 F. Supp. 128, 133 (N.D. Cal. 1972)

44. Hamilton v. Schiro, 938 F. Supp. 1016, 1017 (E.D. La. 1970)

45. Willowbrook I, 357 F. Supp. 752,765 (E.D. N.Y. 1973)

46. Roberts v. Stale, 307 N.E. 2d 501, 505 (Ind. Ct. App. 1974)

47. Kesselbrenner v. Anonymous, 33 N.Y. 2d 161, 350 N.Y.S. 2d 889, 892 (Ct. App. 1973). Sce generally, Burt, note 40 , above, at 759-760.

48. Fernandez $v$. Baruch, 96 N.J. Super. 125, 137, 232 A. 2d 661 (App. Div. 1967), reversed on other grounds 52 N.J. 127, 244 A. 2d 107 (1968)

49. Roe v. Wade, 110 U.S. 113,153-156 (1973)

50. Mackey v. Procunier, 477 F. 2d 877, 878 (9 Cir. 1973); Rumuels \%. Rosendule, 499 F. 2d 733, 735 (9 Cir. 1974)

51. Willowbrook I, 357 F. Supp. 752, 765 (E.D. N.Y. 1973); Lollis v. New York State Depart. ment of Social Services, 322 F. Supp. 473 (S.D. N.Y. 1970), modificd 928 F. Supp. 1115, 1118 (S.D. N.Y. 1971)

52. Knecht v. Gillman, 488 F. 2d 1186, 1139-1140 (8 Cir. 1973); of. Clonce r. Richardson, 379 F. Supp. 338,349 (W.D. Mo. 1974) (mere fact that transfer to behavior modification program is viewed as "treatment" for inmates' benefit does not insulate it from clue process inquiries).

53. Shelton v. Tucker, 364 C.S. 479,488 (1960).

54. Chambers: Alternatives to civil commitment of the mentally ill: Practical guide and con. stitutional imperatives. 70 Mich L Rev 1107, 1145 (1972)

55. Lessard v .Schmidt, 349 F. Supp. 1078, 1096 (E.D. Wis. 1972), vacated on other procedural grounds 414 U.S. 473 (1974), on remand 379 F. Supp. 1376, 1379 (E.D. W'is. 1974), vacated and remanded -U.S.-, 43 U.S.L.W. 3600 (1975); Dixon 7. Altomey Cemeral of Pennsyl. zonia, 325 F. Supp. 966, 974 (M.D. Pa. 1971); Wyall v'. Stickney. 344 F. Supp. 387, 396 (M.D. Ala. 1972), aft'd sub. nom. Wyatt v. Aderholt, 503 F. 2d 1305 (5 Cir. 1974); Welsrh v. Likins, 373 F. Supp. 487, 501-502 (D. Minn. 1974)

56. Sce, e.g., Singer $v$. State, 63 N.J. 319, 323, 307 A. 2 d 94 (1973), implicitly recognizing that the degree of security in hospital placements must be appropriate "in the light of patient's illness."

57. Kent v. Dulles, 357 U.S. 116, 125 (1958); Aptheker v. Secretury of Slate, 378 U.S. 500, 505 (1961)

58. NA.4CP v. Alabama. 357 U.S. 449 (1958); Contes v. City of Cincinnati, 402 U.S. 611 (1971)

59. DeJonge 7. Oregon, 299 U.S. 353 (1937); Lamont x. Postmaster General, 381 U.S. 301 (1965); Sherbert v. Verner, 374 U.S. 398 (1963); Griswold v. Connecticut, 381 C.S. 479 (1965)

60. O'Connor v. Donaldson, -U.S., 43 C.S.L.W. 4929,4933 (1975)

61. Chambers, note 54, above, at 1194, n. 85; Chambers: Right to the least restrictive alternative setting for treatment, in 2 Legal Rights of the Mentally Handicapped 991, 1011-1014 (P.L.I. ed. 1973); Kittrie, note 35, above, at 95-101; Linn: A Handbook of Hospital Psychiatry, Ch. XXXV (I.U.P. ed 1969); Goffman: Asylums (1961); Barton and Rusvell: Institutional Neurosis (2d ed 1966); Stanton and Schwartz: 'The Mental Hospital (1951): Glasscote: Rehabilita- 
tion of the Mentally Ill in the Community (1971); Clark: Social Therapy in Psychiatry (1974)

62. Kaimowilz ". Michigan Dcpl. of Mental Hralth, 42 C.S.L.W. 2063 (Mich. Cir. Ct. 1973) (cxperimental pychonurgery)

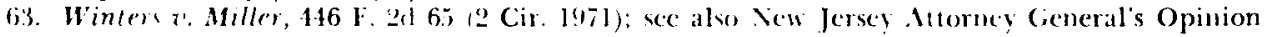
\# M73-1142 (July 31, 1974) (right to refuse medication).

64. P.A.K.C. V. Commonu'ralih of Penmsylamin, 334 F. Supp. 357 (E.1). Pa. 1971): Mill, r. Boward of Education, 348 F. Supp. x66 (1).1).C. 1979); of. Robinson ". Cahill, 62 X.J. 473, 520, $303 \mathrm{~A}$. 2d 273 (1973) (additional expenditures may be necessary to equip disadvantaged childsen for educational opportunities)

65. Dixon v. Allomey General of Pennsylermin, 325 F. Supp. 966, 974 (M.1). Pa. 1971)

66. Souder t. Bremman, 367 F. Supp. 808 (D.D.C. 1973)

67. Carroll r. Cobb, 139 X.J. Supp. 439, - A 2d-(App. Div. 1976)

68. See genetally, Bass: Firt, Sixth and fourcenth Anendment rights in mental institutions, in 2 Legal Rights of the Mentally Handicapped 62I, 623-632 (P.L.I. Cd 1973)

69. See generall, text at pp. 8(1)-81 above.

70. See text accompaning note 9 , above. 